\title{
Discovering Servant Leader Relations with New Followers in Nonprofit Organizations: Does a Servant Leader Always Serve First?
}

\author{
David Neal Ammons', Thomas Chalmers McLaughlin² \\ ${ }^{1}$ Department of Business Administration, Central Texas College, JBER, Alaska, USA \\ ${ }^{2}$ School of Business and Technology Management, Northcentral University, Prescott Valley, Arizona, USA \\ Email: dammons@ctcd.edu,tmclaughlin@ncu.edu
}

How to cite this paper: Ammons, D. N., \& McLaughlin, T. C. (2017). Discovering Servant Leader Relations with New Followers in Nonprofit Organizations: Does a Servant Leader Always Serve First? Open Journal of Leadership, 6, 34-60.

https://doi.org/10.4236/oj1.2017.62003

Received: April 25, 2017

Accepted: June 16, 2017

Published: June 19, 2017

Copyright $\odot 2017$ by authors and Scientific Research Publishing Inc. This work is licensed under the Creative Commons Attribution International License (CC BY 4.0).

http://creativecommons.org/licenses/by/4.0/

\begin{abstract}
This study focused on discovering servant leadership in the nonprofit organization (NPO) of the church with a concentration on new follower relations. The investigation was conducted as an Interpretative Phenomenological Analysis (IPA) so as to be able to capture the life experiences and identifications of the servant leaders in the church clergy. Servant leadership theory is a management model and practice for the business community including large organizations, such as Southwest Airlines, to small businesses and to NPOs, including the church. The problem is the lack of clarity on how clear servant leaders in NPOs cultivate relationships with new followers and empower them to develop a caring community while meeting the NPO's needs. The researchers investigated the experiences of servant leaders to receive and develop new follower relations in the NPO of the Christian Protestant church. The research revealed a potential lack of clarity and the need for specific research on new followers focused on the initial concept of servant leadership; the definition of a servant leader is a leader who serves first. The participants in this study were servant leader pastors from Christian churches in the Northern United States. Two research questions were developed to inquire, first, about how the participant's actions were received when they were new followers and secondly, to inquire about the participants' servant leader undertakings toward their new followers. The data were analyzed and superordinate themes were developed based on data provided by the interviews and the derived interlocking information produced. The resulting superordinate theme for research question one was "Commitment to the Growth of People." The superordinate themes for research question two were "Empowering and Developing People" and "Providing Direction." The results from the interviews and double hermeneutic analysis demonstrated that the servant leader participants taught new followers first and then, once the new follower attained a sufficient
\end{abstract}


basic level of knowledge, were served by these servant leaders. Scholars highly regard the historical individual known as Jesus of Nazereth as one of the original servant leaders and his teachings to his disciples as prime examples of servant leadership guidelines. The generalizability of the research relates to any new follower who receives little to no screening in any organization, like the selected group of the NPO of the church, a secular NPO like the United Way, or a standard business which increases its workforce with little screening. The conclusions of this research study added to the extent information on servant leadership theory. This study can serve as a catalyst for future research regarding new followers using servant leadership.

\section{Keywords}

Ecclesiastical Polity, Followership, Interpretative Phenomenological Analysis (IPA), Nonprofit Organization (NPO), Servant Leadership

\section{Introduction}

The empowerment motivation of new followers has become an essential leadership component for managers in organizations today (Arogundade \& Arogundade, 2015; Van Winkle, Allen, DeVore, \& Winston, 2014). The mobility of the subordinates or followers for personal or professional reasons places an increased burden on leaders (Mullaney, 2014) to integrate and empower followers for the good of the overall vocation and individual not just the organization (Van Winkle, Allen, De Vore, \& Winston, 2014). In this environment, subordinates, or followers have the confidence and knowledge to be real followers (Hoption, 2014) and are therefore empowered to make important decisions, when necessary, to support the overall organizational mission and maintain career satisfaction (Arogundade \& Arogundade, 2015).

Non-profit organizations (NPOs) present unique motivation and empowerment challenges to a leader (Schneider \& George, 2011) with new followers. New followers in some NPOs, like churches, may be either isolated or spectators with the potential to be ignorant of the guiding principles of the organization required to be a true follower (Crippen, 2012). In for-profit ventures, for example entrepreneurships, motivation is largely based on financial reasons (Renko, Kroeck, \& Bullough, 2012). For the organizations, either NPO or for-profit, which have paid employees, the use of hiring managers may check potential employee followers for basic organizational knowledge for a proper long-term leader-follower environment (Schwepker \& Schultz, 2015). The need for a leadership technique to empower followers is critical to an organization's success (Choudhary, Akhtar, \& Zaheer, 2013; Parris \& Peachey, 2013b).

Servant leadership theory posits that the mentor must first serve the follower and the focus of the leader is placed on the followers (Burch, Swails, \& Mills, 2015; Spears, 2010; van Dierendonck, 2011). Greenleaf, the author in the seminal research on the servant leadership theory, described the servant leader as some- 
one of character and moral influence putting the needs of people first while being a good communicator, a compassionate team builder, and systems thinker with vision (Greenleaf, 1977). Van Dierondonck combined 44 different characteristics of servant leader studies down to six characteristics of the theory and actions of a servant leader which are as follows: the elements of empowerment, humbleness, genuineness, relational approval, guidance, and social responsibility (van Dierendonck, 2011). This list of characteristics and elements of a servant leader distinguish this leadership theory from other similar leadership theories, such as transformational leadership theory (Ghasabeh, Reaiche, \& Soosay, 2015). In servant leadership theory there is an emphasis on the individual follower beyond the organization and individual spiritual development, among other things (van Dierendonck, 2011).

Researchers of servant leadership have discerned the empowerment characteristic of servant leadership (Greasley \& Bocârnea, 2014; van Dierendonck, 2011) among several other beneficial characteristics (Greenleaf, 1977; Spears, 2010; van Dierendonck, 2011). Leaders applying the servant leadership theory have been shown to induce positive outcomes in followers and organizations (Hunter et al., 2013) and to be effective in empowering followers in small businesses where the leader has legal authority (Van Winkle, Allen, De Vore, \& Winston, 2014). More research is necessary to broaden the knowledge about servant leaders of other types of organizations, like the NPO of churches, in establishing empowering relationships with new followers (Hoption, 2014).

\subsection{Background}

While the subject of leadership is taught all across the country and is a subject to which many recognize as important, the subject of followership and being a good follower is, in many ways, as important as leadership (Hoption, 2014; Leroy, Anseel, Gardner, \& Sels, 2015). A leader must have followers to be considered a leader (Hoption, 2014). The process of developing and empowering followers is a key role for leaders using transformational or servant leadership (Țebeian, 2012; Washington, Sutton, \& Sauser, 2014). Transformational leadership and servant leadership both emphasize the follower in the leadership style (van Dierendonck, Stam, Boersma, de Windt, \& Alkema, 2014), but servant leadership focuses on the follower for the follower's sake where transformational leadership focuses on the follower for the organizational performance sake (van Dierendonck, 2011). Transactional leadership is another form of leadership that emphasizes the follower but in a give-and-take context as opposed to the empowerment focus of transformational leadership and servant leadership (TTebeian, 2012). Both transformational leadership and servant leadership styles have been shown to be effective for empowerment with advantages in the area of empowerment for servant leadership in small businesses (Van Winkle et al., 2014), volunteer service organizations (Schneider \& George, 2011), and some nonprofit organizations (Parris \& Peachey, 2013b).

Servant leadership theory was developed by Greenleaf to address the ineffec- 
tiveness of the top-down hierarchy management and leadership approach (Greenleaf, 1977). A close collaborator with Greenleaf developed 10 elements of a servant leader; listening, empathy, relationship and emotional healing, consciousness, encouragement, conception, anticipation, stewardship, private assurance to the personal, specialized and nonphysical development of people, and building community (Spears, 2010). Servant leadership theory promotes strong followers through a process of empowerment, an importance placed on moral judgement and an emphasis on building community beyond the specific organization which produces authenticity in the leader (Leroy et al., 2015; Washington et al., 2014).

Within the various conceptualizations of servant leadership is a focus on empowerment (van Dierendonck, 2011), helping subordinates to grow and succeed (Liden, Wayne, Zhao, \& Henderson, 2008), and focus on retention and development of employees (Wong \& Davey, 2007) as initial steps of engaging followers. The elements of the servant leader notwithstanding, the operationalization of the servant leader begin with the idea that a servant leader must serve first (Parris \& Peachey, 2013a; van Dierendonck, 2011). The issue is do the elements mentioned previously of empowerment, aiding in growth and success, and development always address the servant leader engagement of a new follower in reference to Greenleaf's bench mark of a servant leader serving first.

As Jesus of Nazereth, the founder of Christianity, was the one who first taught the concept of servant leadership (Sendjaya \& Sarros, 2002), His differentiation of followers and new followers provides specific insight. In the New King James Version (NKJV) of the Gospel according to St. John 21: 15-17, Jesus has an instructive conversation with Peter and says the following: (15) "So when they had eaten breakfast", Jesus said to Simon Peter, "Simon, son of Jonah, do you love Me more than these?" He said to Him, "Yes, Lord; You know that I love You." He said to him, "Feed My lambs." (16) He said to him again a second time, "Simon, son of Jonah, do you love Me?" He said to Him, "Yes, Lord; You know that I love You." He said to him, "Tend My sheep." (17) He said to him the third time, "Simon, son of Jonah, do you love Me?" Peter was grieved because He said to him the third time, "Do you love Me?" And he said to Him, "Lord, You know all things; You know that I love You." Jesus said to him, "Feed My sheep." There is significance about the specific order of the words of Jesus when He said "Feed my Lambs". Then "Tend my sheep", and then "Feed my sheep" as lambs are new and naïve followers where sheep are standard followers ready to produce; furthermore, within Christianity, feeding is teaching, tending is serving, lambs are new followers, and sheep are more experienced followers (Resane, 2014).

The presence of authenticity in a leader should prompt followers to become authentic followers (Leroy et al., 2015). A follower is not always a position to which one ascribes (Read III, 2014) but it can be a position where individuals start in an organization (Leroy et al., 2015). The element of followership, however, entails an involvement and caring about the success of the organization concerning the individual's success therein (Crippen, 2012; Zou, Tian, \& Liu, 
2015). The development of the leader-follower relationship is about the motivations and empowerment prescribed by the leader within the organization and the leadership style utilized by that leader (Arogundade \& Arogundade, 2015). The follower can bring value to the leader-follower relationship, such as skills and abilities (Read III, 2014), that the manager needs to utilize to develop organizational citizenship behavior (OCB) (Zhong, Lam, \& Chen, 2011).

\subsection{The Problem and Purpose}

The general problem is that it is not clear how servant leaders in NPOs cultivate relationships with new followers and empower them to develop a caring community while meeting the NPO's needs (Parris \& Peachey, 2013b; Schneider \& George, 2011). The specific problem may expose a potential insufficient generalizability of a fundamental assertion of servant leadership, that a servant leader is a leader who serves first (van Dierendonck, 2011), for all management settings. This study will investigate the particular problem, which is the determination of experiences of servant leaders to develop followership relations in new followers (Alvesson \& Blom, 2015) in the NPO of faith organizations. Followership is an active role of the individuals being led in a group who approach their tasks and relationships with a sense of ownership and autonomy for more organizational objective inspiration (Hoption, 2014; Leroy et al., 2015). Many researchers have found that leaders using servant leadership principles empower and inspire followers (Greenleaf, 1977; Parris \& Peachey, 2013a; Spears, 2010; van Dierendonck, 2011). However, the experiences of servant leaders to establish relationships with new followers (Hunter et al., 2013) to be empowered in the NPO of the church has not been evaluated (Carter \& Baghurst, 2014; Parris \& Peachey, 2013b; Van Winkle et al., 2014).

The purpose of this qualitative study was to understand the experiences, relationships, and feelings of participants regarding how servant leaders in the NPO of churches establish rapport with new followers as leaders and how camaraderie was established when the leader was a new follower (Zou et al., 2015). The proposed participants in this study were pastors and chaplains in churches from the Christian background who were deemed to have the characteristics of a servant leadership church (Greenleaf, 1977).

The study used the Interpretative Phenomenological Analysis (IPA) methodology as it secures and probes the meanings that participants assigned to their experiences (Convery, Soane, Dutson, \& Shaw, 2010). The experiences and feelings of the participants were the main subject to be evaluated (Smith, Flowers, \& Larkin, 2009).

The IPA method was used to explore the servant leaders' experiences providing empowerment to new followers in churches. Additionally, the participants were queried as to their individual experiences as new followers when dealing with their leaders at that time. This portion of questions opened the societal interchange relationship of leader and follower from the contributor (Zou et al., 2015) about the faith organizations. The participants were asked open-ended 
questions about their experiences of their new followers and actions needed to advance the purpose of work, proficiency, having a choice in initiating or regulating actions, and influencing outcomes that all provided insight into the practice of empowerment (Arogundade \& Arogundade, 2015). These experiences all contributed to the servant leader empowerment of new followers (Leroy et al., 2015). The participants were of the Christian faith and came from churches in the Northern United States.

\subsection{Theoretical Framework}

This study seeks a possible new element to servant leadership theory with regard to how servant leader pastors, in their role as managers, empower and positively motivate new followers in churches. The theoretical framework and perspective is based on application of the servant leadership theory (Greenleaf, 1977) toward empowerment with the initial handling of new followers to get to the level of active followership (Leroy et al., 2015; Zou et al., 2015). Of all of these elements and characteristics of servant leadership, empowering and developing followers was suggested as having four elements: providing meaning, giving motivation and freedom, establishing self-determination in followers, and competence (Arogundade \& Arogundade, 2015; Van Winkle et al., 2014; Zhong et al., 2011). This insight on empowerment evaluated the follower component of empowerment in three areas, first, as emphasized within an organizational context only (Arogundade \& Arogundade, 2015; Choudhary et al., 2013) second as within the organization and third outside an organization context (Hunter et al., 2013; Parris \& Peachey, 2013a; Van Winkle et al., 2014).

The aspect of servant leadership theory used in the investigation was empowerment for new followers by pastors of churches in relation to the primary directive from Greenleaf that in servant leadership, the leader should first serve (Greenleaf, 1977). This characteristic was evaluated through IPA interviews of the pastors' experiences as leaders toward new followers and their experiences as new followers. It was possible that this research could produce an adjustment or tweak to the definition of the servant leadership theory that the leader should serve first. The process of empowering a new follower in an NPO church produced a revelatory modification with new followers where all participation is voluntary, there is no screening of organizational knowledge (Schneider \& George, 2011), and the entire atmosphere may be completely new to the follower. In this situation, the servant leader may possibly not serve first but might first have to train the follower first to bring him to a state of understanding and active followership (Leroy et al., 2015) whereby the individual can then be served and empowered.

\subsection{History of Related Theories up to the Application of Servant Leadership}

The capability and proclivity of leaders to empower their followers has been a debate in management studies since the McGregor's management theory of 
Theory X and Y (Arogundade \& Arogundade, 2015; McGregor, 1960). Theory X theorizes that workers are lazy and that force from management is needed to compel productivity; while Theory Y views workers as free and ambitious and that other methods of motivation, beyond force are needed for production and productivity (Arogundade \& Arogundade, 2015).

The state of followership is a subject that is rarely taught and developed (Hoption, 2014). The subject of followers is important, as it is impossible for a leader to be a leader without followers (Crippen, 2012; Hoption 2014). The leader-follower interchange is an important topic in leadership studies (Leroy et al., 2015; Zou et al., 2015). New followers in any organization tend to be passive and withdrawn until the individual understands their role in the organization (Leroy et al., 2015; Read III, 2014).

The primary motivational theory relating to servant leadership addresses empowerment, which is an essential characteristic of servant leadership to be analyzed in this dissertation (Parris \& Peachey, 2013a). There are multitudes of motivation theories which generally flow back to McGregor's (1960) Theory X and Theory Y motivation of workers which allows for theory $\mathrm{X}$ to state workers are not free thinkers. Theory X workers must be kept in line while Theory Y states workers are free thinkers and should be encouraged and motivated to think for the best of the organization (Arogundade \& Arogundade, 2015).

This concept was accentuated by Adams (1963), who wrote on the development of the Equity theory that workers are motivated by the sense that machinations in their workplace or other organization are fair and equitable (Tseng \& Kuo, 2014). The Equity Theory was established by Adams (1963) to explain the socio-psychological motivation in relational terms primarily in the workplace regarding fairness and equity (Burrai, Font, \& Cochrane, 2015). Self-worth is a beginning element of self-determination and a contributing factor to empowerment (Arogundade \& Arogundade, 2015).

Expectancy Theory was defined by Vroom (1964) as an individual's performance or motivation and is predicated on their expectation of a reward for their action (Renko et al., 2012). The other elements of the Expectancy Theory are that a greater reward will follow completion of expectations and the reward, or meaning, needs to be considered valuable by the recipient (Vroom, 1964). The elements of expectancy according to Vroom (1964) are expectancy, instrumentality, and valence.

Transactional leadership was a system of leadership where the leader oversees the followers in a series of transactions or rewards for excellent performance and punishment for poor behavior (Epitropaki \& Martin, 2013). Whenever the subordinate is performing just to standard or good, the transactional leader did not interfere with the worker, utilizing a hands-off style although there were some active transactional leaders (Washington et al., 2014). Transactional leaders treated workers fairly within the scope of their duties and, in some ways, served as an extension and reinforcement of impartiality and expectancy through rewards (Deichmann \& Stam, 2015) and clearly could have been the next step to 
actuate the equity motivation and expectancy motivation.

Transformational leadership was considered a continuation of transactional leadership and was considered a better connection to workers (Hamstra et al., 2014). The transformational theory was originally developed by Burns in 1978 and expanded upon by Bass in 1985 to develop a method to increase collective productivity in an organization by emphasizing the individual (Ghasabeh, Reaiche, \& Soosay, 2015). Transformational leaders motivate followers to operate in a first-rate manner for the good of the organization (van Dierendonck, Stam, Boersma, de Windt, \& Alkema, 2014).

Of the seven leadership theories that most overlap with servant leadership, transformational leadership theory represents the theory which most closely resembles servant leadership (van Dierendonck, 2011). In many ways, servant leadership and transformational leadership mirror one another (TTebeian, 2012; van Dierendonck et al., 2014). Both servant leadership theory and transformational leadership theory were developed in the same time frame, as servant leadership was shaped by Greenleaf (1977) and transformational leadership theory was first mentioned by Burns in 1978 and fully developed by Bass in 1985 (van Dierendonck et al., 2014).

The transformational leader and servant leader were still leaders and decisions were made but once the team was developed and empowered, the need for a directive practically ceased as key persons on the team could discuss the decision (van Dierendonck et al., 2014). Transformational leaders and servant leaders shared similar characteristics in relation to the connection, care, and empathy expressed toward the subordinate follower to prompt the completion of tasks; however, transformational leaders placed the focus of these efforts on the success of the organizational mission whereas servant leaders moved beyond the organization to the community and the follower as a person.

Researchers have determined that a manager using servant leadership may possess a strong empowerment potential towards their followers in the context of larger organizations (Sendjaya, 2015), in smaller businesses (Van Winkle et al., 2014), and some NPOs (Parris \& Peachey, 2013b; Van Winkle et al., 2014). The variety of NPOs and circumstances surrounding such ventures, from a temporary softball tournament committee for a good cause to a recognized secular permanent agency like United Way to the church, require more research on how to adopt and cultivate servant leadership elements, like empowerment in a variety of environments (Parris \& Peachey, 2013b).

Several unique obstacles face a researcher attempting to evaluate churches and pastors specifically for management techniques to empower and communicate to followers (Watt, 2014). There is an attitude among some pastors and chaplains who view the church as a sacred entity that is primarily concerned with the spiritual elements and should not be subject to the secular principles and systems of management (Pfang, 2015) like servant leadership. Pastors and chaplains have to understand church government, theology, the spiritual formation of the followers, and, even, politics with sometimes little to no management training 
(Watt, 2014).

This study fills in gaps in the research regarding servant leadership by specifically looking at a unique central characteristic and the setting in the experiences of servant leader pastors in churches dealing with new followers and their training and applying the servant leadership element of empowerment to this training. Additionally, the pastors' experiences of engaging the four elements of empowerment of providing the training, fostering motivation and freedom, establishing self-determination in followers, and competence (Arogundade \& Arogundade, 2015; Van Winkle et al., 2014; Zhong, Lam, \& Chen, 2011) were not only analyzed through servant leadership but also through the lenses of other theories. Servant leadership in tandem with other theories cover elements of empowerment (Adams, 1963; Washington et al., 2014). The Bible in used in for this study as a workplace leadership manual for the participants of servant leadership from the example and teaching of the first servant leader, Jesus (Sendjaya \& Sarros, 2002).

\subsection{Research Questions}

This study provides insight into how servant leaders in churches are effective in the integration of new followers toward empowerment. Servant leaders in churches have a challenging role in overseeing an NPO with new followers who volunteer where empowerment is a facilitator of the influences of servant leadership (Schneider \& George, 2011). It is essential for NPOs to inspire involvement from followers in order to develop both financial and human capital (Parris \& Peachey, 2013b). While the church is not a company in the business/secular sense as it is not a commercial, profit-making organization, nevertheless, good management practices are both pertinent and applicable to the church (Pfang, 2015). The research questions were:

Q1. How do servant leader pastors in churches of the Christian faith in the Northern United States make meaning of their own experiences as new followers in relation to the rapport-building they received?

Q2. How do servant leader pastors in churches of the Christian faith in the Northern United States make meaning of their experiences of establishing relationships with new followers as a leader toward the objective of building community, inspiration, and empowerment of their new followers?

\subsection{Nature and Significance of the Study}

The usage of servant leadership by pastors of Christian churches in their enabling of their new followers in servant leader empowerment is analogous to the enabling of empowerment in small businesses (Van Winkle et al., 2014), volunteer service organizations (Schneider \& George, 2011), and large organizations (Parris \& Peachey, 2013b; Watt, 2014). The concern with using a quantitative study is the sample size needed for such a study and the nature of abstracting the broad experiences, beliefs, relationships, feelings, and values of a pastor or chaplain into closed questions (Smith et al., 2009). The research method for this dis- 
sertation was a qualitative study, specifically an Interpretative Phenomenological Analysis (IPA), which described the experiences of the pastors and chaplains as related to the empowerment of their new followers and their experiences as a new follower (Moustakas, 1994; Smith et al., 2009).

The research for this problem revealed a lack of clarity and specific research focused on the initial concept of servant leadership, which is that a servant leader is a leader who serves first (Greenleaf, 1977; Parris \& Peachey, 2013a). This difficulty relates to the applicability of the notion of servant leadership in all its encounters with followers (Leroy et al., 2015), including actions needed for NPOs (Parris \& Peachey, 2013b; Schneider \& George, 2011). If the problem of clarity about the initial first step of the servant leadership theory is not settled and clarified for all management situations, including the church NPO (Parris \& Peachey, 2013b), then the proper treatment of new followers (Hoption, 2014) using servant leadership may face implementation challenges. Servant leadership theory application has been empirically tested in many types of organizations (van Dierendonck, 2011) to show effectiveness in numerous contexts dealing with followers (Alvesson \& Blom, 2015; Hoption, 2014) to include empowerment (Schneider \& George, 2011; Van Winkle et al., 2014). This is in regard to the theoretical understanding of servant leader empowerment (Greasley \& Bocârnea, 2014; Sun, 2013; van Dierendonck, 2011) in all settings (Schneider \& George, 2011; Van Winkle et al., 2014).

\section{Overview of Servant Leadership, Followership and Ecumenical Polities}

\subsection{Servant Leadership}

Servant leadership theory was designed by Greenleaf (1977) as a rational management counterbalance to hierarchical systems of organizations (Parris \& Peachey, 2013a). The systems of management and leadership in traditional settings are often structurally rigid and often may not benefit all of an organization's component membership (van Dierendonck, 2011). On this kind of setting, the focus of the manager can be focused more on control and completing the assigned task rather than creating an atmosphere where the subordinates could flourish and even be considered for management in the future (Zou et al., 2015). Greenleaf coined the term "servant leader" for describing the character and nature of the position and status of the non-hierarchical leader (Spears, 2010).

Researchers have stated that the closest leadership theory to servant leadership theory was that of transformational leadership, which shares many similarities to servant leadership (Parris \& Peachey, 2013a; Țebeian, 2012; van Dierendonck, 2011). Determining and identifying empowerment for followers on the part of a leader using servant leadership is challenging (Parris \& Peachey, 2013a; van Dierendonck, 2011). When the servant leader was a pastor or chaplain of a Christian Church, the identification of necessary leadership carries additional challenges (Pfang, 2015; Watt, 2014) as the followers may have volunteered (Parris \& Peachey, 2013a) in a unique spiritual environment. 
Identifying individual attributes of what constitutes a servant leader have begun with the concept of a positive self-esteem (Sun, 2013). While this quality seemed like it could be included in the attributes of many leadership types, the charismatic leader was determined to be low on a self-esteem scale (Sendjaya, 2015). More importantly, however, an analysis of other servant leader attributes revealed the ability of the servant leader to genuinely care for the state of others as essential and prerequisite (Sun, 2013; van Dierendonck, 2011) while developing a strong aptitude and ability to exhibit a social influence (Choudhary et al., 2013; Sun, 2013). Figure 1 shows the framework for identifying the servant leadership and depicts how the identity starts with a calling to serve, and is composed of cognitive dispositions and behavioral characteristics.

Figure 1 shows that Servant Identity attributes and individual traits contribute to an individual's efficacy in leadership when accompanied by cognitive and behavioral dispositions that facilitate primary processing and action. Adapted from "The Servant Identity: Influences on the Cognition and Behavior of Servant Leaders," by P. Sun, 2013, The Leadership Quarterly, 24, p. 546. Copyright 2013 by the Leadership Quarterly. Reprinted with permission.

Figure 2 established the model for servant leadership which starts with a call to serve with a desire to lead which reveals six relevant and important characteristics. Solid leader-follower relationships and conviction produces which makes possible empowerment and the ability to empower, OCB, and perseverance at the individual and organizational level. Adapted from "Servant Leadership: A Review and Synthesis," by D. van Dierendonck, 2011, Journal of Management, 37(4), p. 1233. Copyright 2011 by Journal of Management. Reprinted with permission.

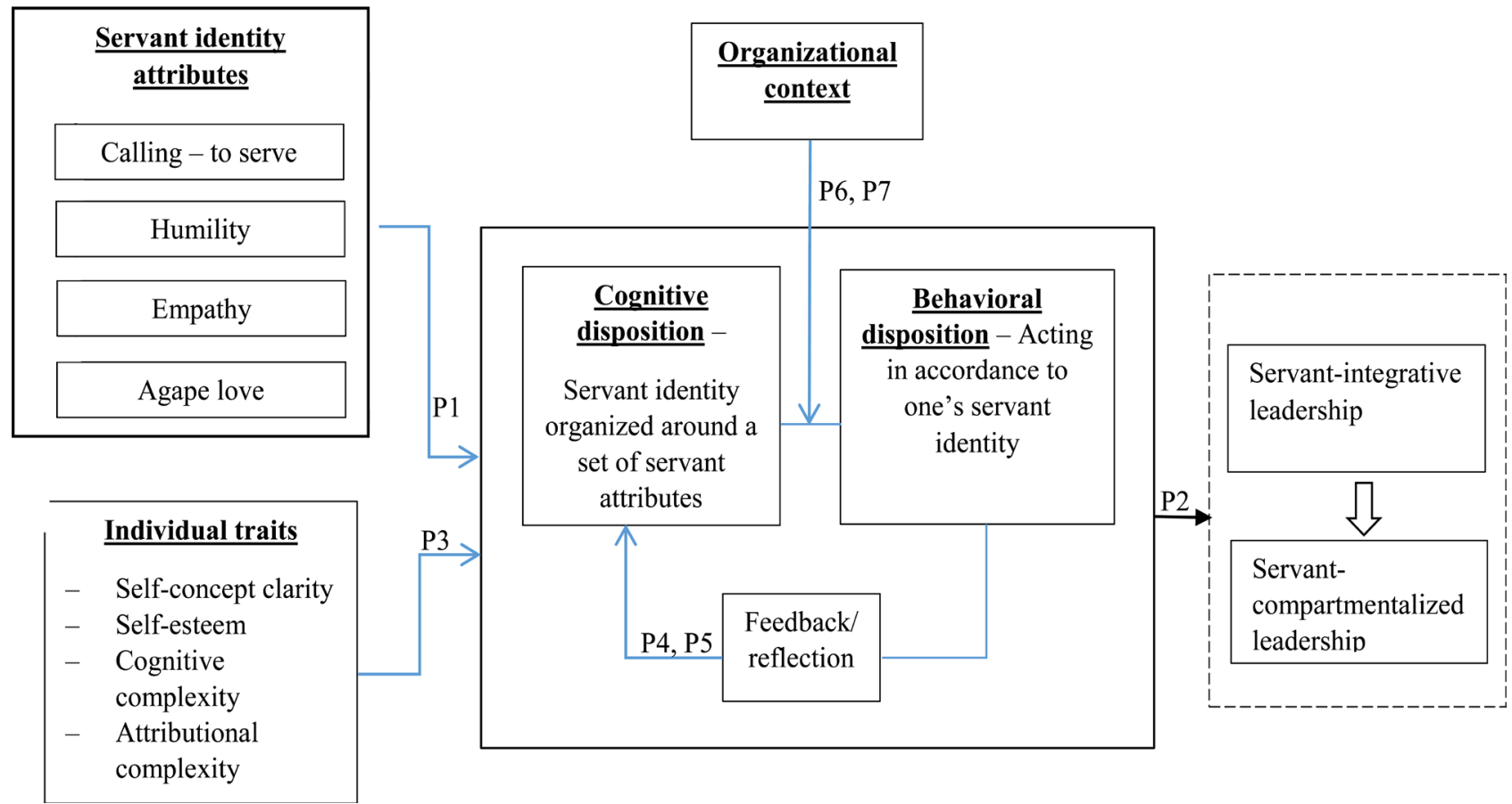

Figure 1. A framework for the servant identity. 


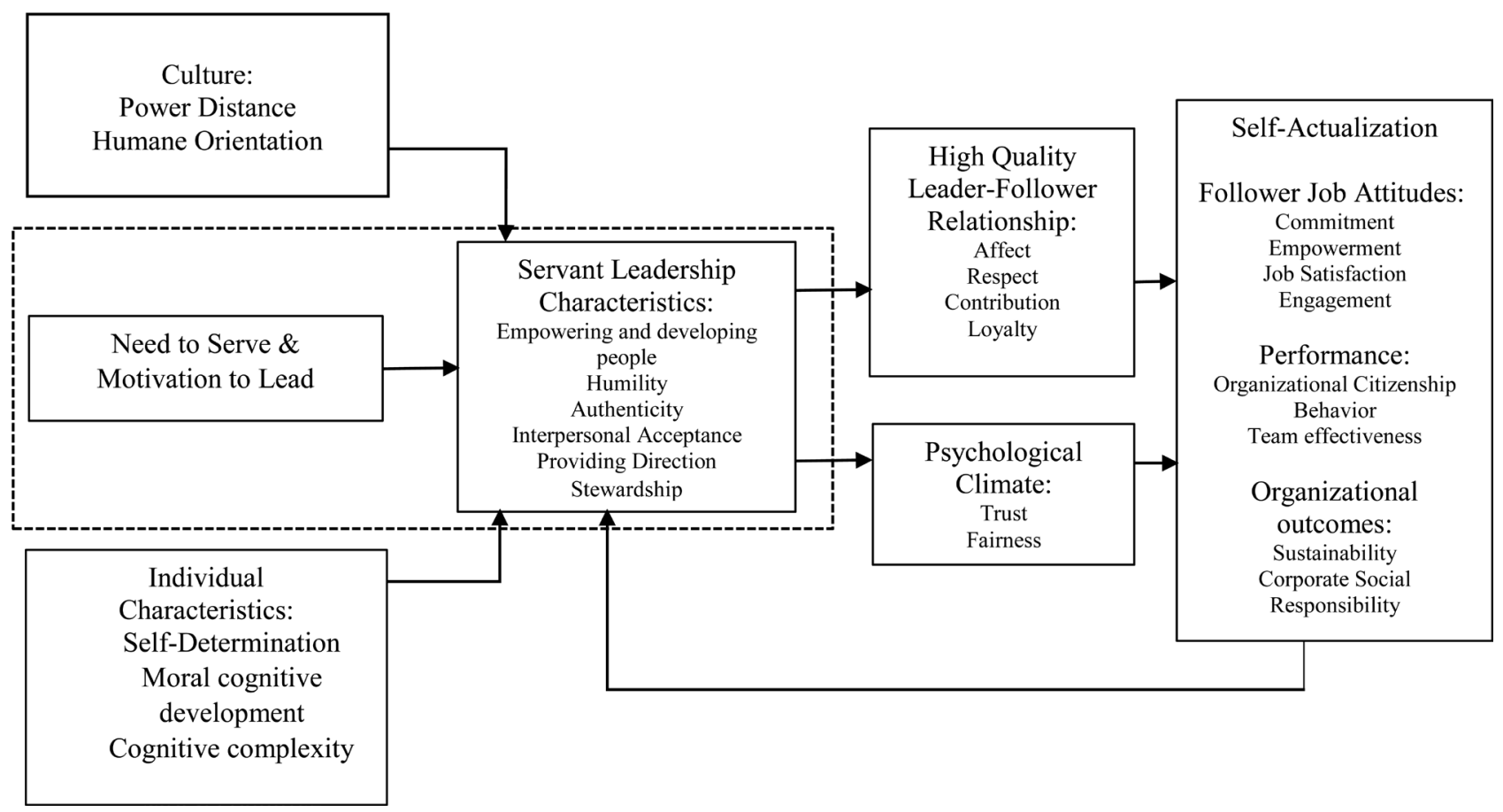

Figure 2. A conceptual model of servant leadership.

The purpose of Figure 1 and Figure 2 was to show the identity of the servant leader (Sun, 2013) and the concept of the servant leadership theory (van Dierendonck, 2011), which embodies the core of the servant leader the presence of which is to be investigated in the servant leader pastor participants of this research project to be presented in this proposal. Each figure displays two of the most important elements of the servant leader and the servant leadership theory: the identity of the servant leader (Boone \& Makhani, 2012; Sun, 2013) and the concept of the servant leadership (Sendjaya, 2015; van Dierendonck, 2011). Sendjaya (2015) noted that the concept of the servant leader expands and builds upon the concept of the transformational leader in its focus on followers' needs and its emphasis on community and corporate social responsibility (Sendjaya, 2015). Figure 1 and Figure 2 show the charts of the traditional concept and servant leader identity which can be used as a guide, or standard for servant leadership, when mapping the emergent themes from the IPA interviews (Wagstaff \& Williams, 2014).

\subsection{Followership}

Very few people ever grow up thinking about how they can be a good follower (Alvesson \& Blom, 2015). Being a good follower is understudied as compared to being a leader as few people desired followership as a life goal (Crippen, 2012). Without followers, there would be no leaders (Zou et al., 2015). Leadership has many definitions, but the general idea is that a leader was an individual who influenced others to accomplish a purpose, mission, or goal (Hoption, 2014; Leroy et al., 2015).

While the transformational leader along with the servant leader promotes 
positive self-identity, the effective administration of servant leadership also promotes positive group identification (p. 517). Ultimately, the role of follower completed leadership as some had stated that a leader was only a leader when there were voluntary followers (Kessler \& Kretzschmar, 2015). The overall effectiveness of the leader and methods was defined by the production and efficiency of the followers individually and as a team (Rahn, Jawahar, Scrimpshire, \& Stone, 2016).

\subsection{Christian Ecumenical Organization and Ecclesiastical Polity}

The determination for identifying Christian Church pastors who are servant leaders concerns the individual clergy's attitude toward an effective management plan within his or his church, particularly dealing with worshippers both new and seasoned (Boggs \& Fields, 2010). Individual attitudes notwithstanding the church polity, or government, had an additional influence on the overseer's ability to effectively provide support to congregants (Wollschleger, 2013) or provide empowerment through servant leadership. Polity is the identification of the form of church government and the established protocols and policies informing the church's ministry in terms of preaching, sacramental procedures, and the scope of the pastor's influence (Avis, 2016).

Within the major mainline denominations of the Christian community, there are three separate forms of church government and organization, otherwise known as Ecclesiastical polity (Avis, 2016). Each type of polity represents a different structure, kind of guidance, and covers different denominations (Wollschleger, 2013). The three types of polities are the episcopal polity, the Presbyterian polity, and the congregational polity (Avis, 2016).

The episcopal polity has the most structured, top-down approach to managing church government in which a Bishop oversees all of the operations of the local church (Wollschleger, 2013). This polity has been used by the Catholic Church and the Episcopal Church (Avis, 2016). This is a definite top-down approach to guiding and leading parishioners (Pfang, 2015). The Presbyterian polity, however, established a different government from the Episcopal organization with a board of elders, or presbyters, responsible for the oversight of the local church (Mutch, 2012). The primary difference between this polity and Episcopal polity is the group of elders, which are elected lay members. The congregational polity recognizes the authority of the congregants of the local church (Avis, 2016; Wollschleger, 2013). Thus, the authority of the pastor is derived from the local congregation who had the power to vote on the pastor or to remove him, which mirrors a democratic form of government (Wollschleger, 2013).

\section{Research Method and Findings: Serve First?}

The IPA method was used to explore the servant leaders' experiences providing empowerment to new followers in churches. Additionally, the participants were queried as to their individual experiences as new followers when dealing with their leaders. The questions asked of participants in this research sought to 
gather data on the societal interchange relationship of leader and followers (Zou et al., 2015) about the faith organizations. Specifically, the participants were asked open-ended questions about their experiences as new followers and actions they deemed necessary to advance the purpose of work, to foster proficiency, and who they felt about having a choice in initiating or regulating actions and influencing outcomes, with the intent of providing insight into the practice of empowerment (Arogundade \& Arogundade, 2015). These experiences all contribute to the servant leader empowerment of new followers (Leroy et al., 2015). The participants came from churches in the northern United States of the Christian faith that exhibited the components of a servant leader in church settings which were evaluated in terms of leader-follower equality, how pastors focus on followers, and whether the church has trustees (Greenleaf, 1977). If the problem of clarity addressed in this research about the initial first steps of the servant leadership theory is not settled and clarified for all management situations (Parris \& Peachey, 2013b), then the proper treatment of new followers (Hoption, 2014) using servant leadership may be diminished. This is particularly true with regard to the theoretical understanding of servant leader empowerment (Greasley \& Bocârnea, 2014; Sun, 2013; van Dierendonck, 2011) in all settings (Schneider \& George, 2011; Van Winkle et al., 2014).

The use of servant leadership by pastors of Christian churches to empower their new followers is a new design similar to servant leader empowerment in small businesses (Van Winkle et al., 2014), volunteer service organizations (Schneider \& George, 2011), and large organizations but not the church or pastors (Parris \& Peachey, 2013b; Watt, 2014). Pastors are trained in many aspects of the church management and may hold a sensitive and permanent position where they are aware knowledge about past actions is in their domain, and where they may have experiences that would be beneficial to share (Watt, 2014).

An investigation of the process of servant leadership through providing instruction to develop empowerment was assessed along with six characteristics implicit in the theory and actions of servant leadership: empowerment, humbleness, genuineness, relational approval, guidance, and social responsibility (van Dierendonck, 2011). These elements were evaluated in the qualitative interviews of the experiences of NPO servant leaders' empowerment of followers. In particular, an investigation was performed to assess the experiences of servant leaders with regard to their (a) enablement of followers to have impact in the church, (b) promotion of social responsibility, (c) commitment to the growth of the people in their purview, (d) delivery of administrative protocols, and (e) understanding of the feelings of the parishioners or followers (Spears, 2010; van Dierendonck \& Nuijten, 2011; van Dierendonck \& Patterson, 2015; Van Winkle et al., 2014).

The specific problem under investigation involves the determination of the experiences of servant leaders in how they engage in followership relations with new followers (Alvesson \& Blom, 2015) in the NPOs of faith organizations. It was not clear how servant leaders in NPOs cultivate relationships with new fol- 
lowers and empower these new followers to develop a caring community while concomitantly meeting the organizational needs of their churches (Parris \& Peachey, 2013b; Schneider \& George, 2011). This research project examined the activities and actions of pastors in their role as managers of nonprofit organizations, specifically churches and how these pastors use servant leadership to engage their new followers. This research study investigated the leadership methods applied by servant leader pastors for new followers and whether the pastor-participants established the leader-member servant leader exchange approach to the new follower by serving them first, as prescribed by servant leadership theory (Parris \& Peachey, 2013a; Sun, 2013; van Dierendonck, 2011) or taught the new follower first then served them once the new follower was established. The serve-first or teach-first approach for new followers was studied through IPA interviews and analysis of pastors in assessing the meaning they apply to their experience as servant leaders as well as their experiences when they were new followers.

\subsection{Demographics}

The individual participants had a broad array of life experiences as well as their variations in the kinds of churches they represent. In relation to previous employment, four of the six participants were or are currently serving in the United States military. The participants in this study were given non-gender specific names of Chris, Jordan, Lynn, Pat, Riley and Terry with descriptions using alternating pronouns (Table 1).

Table 1. Profile of the participants.

Chris. Chris is originally from a state on the east coast. As a child, he attended a different type of church than the one he is ordained in at present. He remembers attending a camp as a young person that provided strong guidance and spiritual influence, particularly naming one counselor as quite influential.

Jordan. Jordan is originally from a state from the south. He is the son of a pastor and is affectionately known as a "preacher's kid" or "PK." Jordan said while there were "issues with his parents and they occasionally argued," Jordan, however, "never fell away from the church." He is married with two children and met his spouse, who is a "PK" too, while in high school.

Lynn. Lynn's background is that he was the son of college professors and began his upbringing in a different church than he would eventually serve in as a minister. He was from a West Coast State originally and generally sought to follow in his parent's footsteps in education. His parents were pioneers in higher education for the area. Lynn came to this Northwestern State after college to look for work.

Pat. Pat originally hails from a mid-western State. He was not raised in a church-going family because of a situation that occurred between his father and the local pastor when he was young. Consequently, he was not raised in the church. When he was around 16, he started to go to church primarily influenced by romantic interest. However, after several visits, he was convinced that the leadership and serving in the church was a direction for him.

Riley. Riley is actively serving in the United States military. He is originally from a mid-western State and was a pastor for many years in that state. His influence within church started when he was a young teenager, but he did not know how to proceed with his calling. He was invited by a minister from a different group of churches to go to a special conference with a well-known religious speaker. A counselor at that conference provided Riley with the information he needed to act effectively on the calling he received many years earlier.

Terry. Terry is originally from a state in the deep south. He served in the military for a considerable length of time which brought him and his spouse to the Northwestern State of this study of this study. His experience with the church began with an encounter with a Chaplain at a hospital. Terry and his spouse just lost a baby, and that Chaplain was there to comfort both of them. His appreciation of that chaplain led him and his spouse to attend chapel services and six months later decided to become serious in his faith.

Note: The use of the male pronoun should not be interpreted as gender identification of participant. 
All of the participants were familiar with the Servant Leadership theory. An investigation of the process of servant leadership was assessed along with six characteristics of the theory and the actions of a servant leader, which are empowerment, humbleness, genuineness, relational approval, guidance, and social responsibility (van Dierendonck, 2011). These factors were evaluated in the qualitative interviews of the experiences of the participants. This study focused on an investigation into the experiences of servant leaders toward their (a) enablement of followers to impact the church, (b) promotion of social responsibility, (c) commitment to the growth of people, (d) delivery of administration, and (e) understanding of the feelings of the parishioner or follower (Spears, 2010; van Dierendonck \& Nuijten, 2011; van Dierendonck \& Patterson, 2015; Van Winkle et al., 2014) was performed. Liden contends that serving others first involves instilling self-confidence in followers (Liden et al., 2008), while Sendjaya states that leadership is more "caught" than "taught" (Sendjaya, 2015). All of the participants were new followers and are now leaders in the church. The first research question related to the participants when they were a new follower.

The evaluation of the participants provided data in determining whether their experiences with implementing servant leadership with new followers included instilling self-confidence through example or, instead, teaching basic principles first then setting the example by role modeling leadership behavior. Many of them learned about servant leadership in their higher education studies. Most, however, never learned about the application of servant leadership until they started working in a leadership position within the NPO of their churches. In all interviews, the participants emphasized the element of providing direction, in some form, of servant leadership when interacting with new followers.

Participants were of a church or belief system that shares characteristics from multiple church organizations. A limitation with the participants was the difficulty of pastors who often counseled and interviewed people to be interviewed themselves. The participants were all determined to be servant leaders because their knowledge of servant leadership, their humility, and based off of Greenleaf's components of a servant leader church which were the leader's ideas and constitution toward leader-follower equality, a pastor known to be focused on followers, and whether the church had trustees (Greenleaf, 1977).

The demographic information from the participants in this study demonstrated a broad array of experience, a variation of churches and polities, and age which showed an overall depth of perspective. The participants from this study were pastors, former chaplains, current chaplains and former pastors who agreed to take part in the interview portion of this study. All five of the Master's degrees referred to in Table 2 were a Master of Divinity degree. In relation to the application of their degree, two individuals were public school teachers before heeding the call to ministry. The information in Table 2 shows the variety of demographic background information from the participants learned from the interviews. 
Table 2. Demographic information from participants.

\begin{tabular}{|c|c|c|c|c|c|}
\hline Church represented & Polity & Age & Marital status & Ethnicity & Education level \\
\hline Baptist $(\mathrm{n}=1)$ & Combined $_{\mathrm{a}}(\mathrm{n}=1)$ & $45-66(M=58)_{b}$ & Married $(\mathrm{n}=5)$ & Caucasian $(n=5)$ & Bachelor's $(\mathrm{n}=1)$ \\
\hline Disciples of Christ $(\mathrm{n}=1)$ & Congregational $(\mathrm{n}=3)$ & & Single $(n=1)$ & Other $_{c}(n=1)$ & Master's $(\mathrm{n}=5)$ \\
\hline Episcopalian $(\mathrm{n}=1)$ & Episcopal $(\mathrm{n}=1)$ & & & & \\
\hline Lutheran $(\mathrm{n}=1)$ & Presbyterian $(\mathrm{n}=1)$ & & & & \\
\hline \multicolumn{6}{|l|}{ Non-Denominational $(\mathrm{n}=1)$} \\
\hline Presbyterian $(\mathrm{n}=1)$ & & & & & \\
\hline
\end{tabular}

Note: $a$ The "Combined" polity is a mixture of Congregational and Presbyterian polity. $b$ The "M" equals Mean of the represented age range. $c$ Specific identification of ethnicity may identify the participant.

\subsection{Themes}

The themes as developed using IPA are central to the understanding of how the subject matter can be interpreted and developed into properly evaluating the findings (Cope, 2011). All of the participants spoke of servant leadership as the preeminent process for the church and referred to other similar theories, such as Shepherd Leadership (Resane, 2014), as derivatives of servant leadership. The characteristics of servant leadership which were uncovered were empowering and developing people, humility, authenticity, interpersonal acceptance, providing direction, and stewardship (van Dierendonck, 2011) as seen in Figure 2. Additionally, the individual characteristics of moral cognitive development and cognitive complexity were included as important to the core servant leadership characteristics because the focus on psychological needs and moral development of followers is significantly heightened for servant leadership as compared to transformational leadership (van Dierendonck et al., 2014). Servant identity attributes of calling to serve, humility, empathy and agape love, as seen in Figure 1 (Sun, 2013), were also included as factors for the themes evaluated from the participants. This study suggested that a new follower in a church should be taught first which presents the human side of the story (Jacob \& Furgerson, 2012) of management in many fields.

The themes developed in this study were from two research questions which are listed again in this section. The first issue was about the participants' memory of the actions taken when they were new followers. The results reflect the phenomenological exploration of the following research questions for research question one.

Q1. How do servant leader Pastors in churches of the Christian faith in the Northern United States make meaning of their own experiences as new followers in relation to the rapport-building they received?

As servant leadership was discussed in terms of new followers, the clergy first discussed their treatment when they were new disciples from research question one. Each of the participants revealed, often emotionally, a connection to the agape love of God as important to their way of life and life choice. Servant leadership literature has shown this type of love as a foundation to servant identity 
(van Dierendonck, \& Patterson, 2015). This connection propelled them to reflect on their calling to serve as a core aspect of their position in the clergy and their individual persona. The calling to serve was fundamental to the beginning elements of the connection to followers using servant leadership (Noland \& Richards, 2015; Sun, 2013) and not just for religious leaders.

The evaluation of the answers for the first research question of how do servant leader pastors in churches of the Christian faith in the Northern United States make meaning of their own experiences as new followers in relation to the rapport-building they received showed that all of the participants replied with answers related to the issue that they were provided direction. In their experience, all of them spoke of someone or several people who talked to them, demonstrated a new kind of love to them, and welcomed them into their group. The way in which they were provided direction differentiated to some degree; however, the guidance and direction were the next step after entry into the place of a new follower.

The superordinate theme for the first research question of the pastors' experiences from their servant leaders as new followers themselves revealed a commitment to the growth of people (Spears, 2010; van Dierendonck, 2011) as the superordinate theme. The sub-themes as mentioned by the participants were reading and study, ability to ask questions, steering and guidance.

Q2. How do servant leader pastors in churches of the Christian faith in the Northern United States make meaning of their experiences of establishing relationships with new followers as a leader toward the objective of building community, inspiration, and empowerment of their new followers?

The second research question was in reference to the servant leader pastors and how they effectively used servant leadership methods for their new followers. The superordinate themes were empowering and developing people and providing direction. The subthemes for the superordinate theme of empowering and developing people were from the participants and were unity, the need to be seen and esteem, teamwork, and providing a place to serve. The subthemes for the superordinate theme of providing direction were to always be available to help, teaching, and set the example. Participants responded to research question two about how they as servant leaders dealt with their new followers and the research interpreted in relation to the literature.

\subsection{Evaluation of Findings}

This IPA study was designed to examine how leaders in a NPO conduct servant leadership with new followers and how those same individuals were treated when they were new followers. The leaders who were chosen were pastors, the nonprofit organization was the Christian church, and the specific design of the church they represented in addition to the church they started in as a new follower was factored in the selection process to match the standards of a servant leadership in a church as set forth by Greenleaf (Grandy, 2013).

Each sub-theme was accompanied by the literature support of the sub-theme 
and how the finding was evaluated with the extant research and literature on that topic. A key quote from a participant specifically confirming the sub-theme was included to bring together the sub-theme with the literature support within this specific research project. There were several quotes from different participants that could have been used as each superordinate theme and sub-theme required a supermajority, and often unanimity, of participant comments related to a sub-theme for this researcher to include that sub-theme within the analysis. The analysis of the researcher's interpretation of the participant's answers yielded additional information about the structure of the interview and the clear understanding that new followers were handled differently.

The questions for this study were open-ended questions chosen to represent a solid cross-level representation of servant leadership from scholars and from the primary servant leadership manual for the participants, the Bible. The initial questions posed were to answer basic demographic questions to evaluate background in relation to basic servant leader structure of their church. The next group of questions were established for research question one about their experiences of receiving servant leadership when they became a Christian. The data were enlightening as elements from Liden about receiving help to grow and succeed (Liden et al., 2008) were balance with becoming part of a faith community (van Dierendonck, 2011). The final third of questions challenged the participants to reveal their specific experiences of dealing with their new followers from specific passages from their primary servant leadership manual, the Bible. The participant's individual answers to interpretation questions revealed their actions toward their new followers through a coding of the themes of this IPA Study (Smith et al., 2009).

After going through the extensive answers and experiences shared from each interview, a method of clustering and labeling thematic experiences was conducted (Moustakas, 1994). The element of the IPA method which differs from other qualitative methods is that the researcher focuses on personal meaning in a certain background for people who share an experience (Smith et al., 2009). So when the initial questions beyond the demographic questions for research question one focused on the participant's experiences receiving servant leadership at the point of becoming a Christian, which was a shared experience from six Pastors or former Pastors from six different types of churches.

The process of IPA and collecting data in this study consisted of finding six participants who held the desired position of the subject of this study. Furthermore, the initial goal was to determine through background checks of the participant's particular office and an overall interpretation from the interviews to determine if the subject was a servant leader. If a participant either did not qualify from the initial checks or from the initial interview questions, another participant would have been sought out to complete the sis required participants. The data analysis consisted of listening and reading, from the transcripts, for certain key words, analyze those words to discover themes which, when combined with other themes, formed the superordinate themes. Figure three briefly 
shows this process with key quotes from participants.

Table 3 below lists the complete structure of the results of research question one and research question two. Research question one posed the question to the participants about the servant leader techniques used by their leader towards them when they were new followers. The results of this research question produced the superordinate theme of Commitment to the Growth of People. Research question two asked the interviewees to reply with their techniques used with their new followers. This research question prompted two superordinate themes of Empowering and Developing People and Providing Direction.

\section{Implications for Future Research}

One main assertion of the servant leadership theory developed by Greenleaf (1977) was a servant leader is a leader who serves or tends first (Parris \& Peachey, 2013a; Sendjaya, 2015; van Dierendonck, 2011). The problem was that past studies may not have been clear how servant leaders in NPOs cultivate relationships with new followers and empower new followers to develop a caring community while meeting the NPO's needs (Parris \& Peachey, 2013b; Schneider, \& George, 2011). This may have exposed a potential insufficient generalizability of this fundamental assertion of servant leadership for all management settings

Table 3. Superordinate and sub-themes, literature support and key quotes.

\begin{tabular}{|c|c|c|c|}
\hline $\begin{array}{l}\text { Superordinate } \\
\text { theme }\end{array}$ & Sub-themes & $\begin{array}{l}\text { Literature support } \\
\text { of theme }\end{array}$ & Key quote from a participant \\
\hline \multirow{3}{*}{$\begin{array}{l}\text { Commitment to } \\
\text { the growth of } \\
\text { people (RQ1) }\end{array}$} & 1. Reading and study & Individual growth $_{\mathrm{a}}$ & $\begin{array}{l}\text { Lynn: His teaching was very academic. He gave me a huge book } \\
\text { and said "here read this". }\end{array}$ \\
\hline & 2. Ability to ask questions & Specialized growth $_{b}$ & $\begin{array}{l}\text { Pat: I asked him questions and he would try to answer my } \\
\text { questions. I didn't know enough to ask good questions. }\end{array}$ \\
\hline & 3. Steering and guidance & Spiritual growth $_{b}$ & $\begin{array}{l}\text { Chris: I would give credit to the } \ldots \text { the camp by giving me } \\
\text { guidance. Steering me into balance. }\end{array}$ \\
\hline \multirow{3}{*}{$\begin{array}{l}\text { Empowering and } \\
\text { developing people } \\
\text { (RQ2) }\end{array}$} & 1. Unity and teamwork & Inclusion and learning ${ }_{c}$ & $\begin{array}{l}\text { Jordan: I do think that I can work with a variety of people. I value } \\
\text { unity and sticking together. }\end{array}$ \\
\hline & $\begin{array}{l}\text { 2. Need to be seen and } \\
\text { esteem }\end{array}$ & Grow and progress ${ }_{\mathrm{d}}$ & $\begin{array}{l}\text { Lynn: You have to be seen. To be a good leader, you have to be seen } \\
\text { by your people where they are. But they need to see you because } \\
\text { then they know you care. }\end{array}$ \\
\hline & 3.Providing a place to serve & Purpose $_{\mathrm{e}}$ & $\begin{array}{l}\text { Terry: I always try to help a new Christian and finding a place to } \\
\text { serve. I use serving as a discipleship tool. }\end{array}$ \\
\hline \multirow{3}{*}{$\begin{array}{c}\text { Providing } \\
\text { direction (RQ2) }\end{array}$} & $\begin{array}{l}\text { 1. Always be available to } \\
\text { help }\end{array}$ & Account-ability $_{\mathrm{f}}$ & $\begin{array}{l}\text { Pat: The fact is, is that He is saying here "Tend my Lambs" because } \\
\text { there are a lot of young believers. Feeding is teaching. }\end{array}$ \\
\hline & 2.Teaching & Expectation $_{\mathrm{g}}$ & $\begin{array}{l}\text { Riley: I always thought I was an encourager but the results were } \\
\text { that I was a teacher. }\end{array}$ \\
\hline & 3. Set the example & New approaches ${ }_{b}$ & $\begin{array}{l}\text { Pat: I think Servant Leadership is being able to set the example. } \\
\text { When it comes to giving, we should set the example in giving, } \\
\text { when it comes to working with people, you set the example. A } \\
\text { leader needs to set the example. }\end{array}$ \\
\hline
\end{tabular}

Note: Literature Support References are as follows: a (Watt, 2014); b (van Dierendonck, 2011); c (Sun, 2013); d (Spears, 2010); e (van Dierendonck \& Patterson, 2015); f (de Sousa \& van Dierendonck, 2014); g (Resane, 2014). 
with new followers.

This study investigated the specific problem, which was the determination of experiences of servant leaders to develop followership relations in new followers (Alvesson \& Blom, 2015) in the NPO of faith organizations. Followership was an active role of the individuals being led in an organization who approach their tasks and relationships with a sense of ownership and autonomy for more organizational objective inspiration (Hoption, 2014; Leroy, Anseel, Gardner, \& Sels, 2015). Many researchers have found that leaders using servant leadership principles empower and inspire followers (Greenleaf, 1977; Parris \& Peachey, 2013a; Spears, 2010; van Dierendonck, 2011). However, the experiences of servant leaders to establish relationships with new followers (Hunter et al., 2013) in order to be empowered in the NPO of the church has not been evaluated (Carter \& Baghurst, 2014; Parris \& Peachey, 2013b; Van Winkle et al., 2014).

The research results clearly showed that there could be a connection between the function of servant leadership in the NPO of the church with new followers though teaching first then serving. These experiences, which were described through the qualitative interviews from six different servant leader pastors with many years of experience, were clearly interrelated with the issues related to behavior when teaching new followers and so aligned with the research (Resane, 2014). Other comments from the participants about love, encouragement, and authenticity coming early were important to consider, but these actions clearly came before any decisions were made to become a follower.

The interrelated responses were particularly significant because these pastors led six different church groups governed by three different polities. The application to businesses was that each polity represented a different approach to leadership which applies to business management. The Episcopal polity represented the top-down hierarchical approach; the Presbyterian polity represented a flatter yet hierarchical approach to management and the Congregational polity represented a flat leadership approach (Wollschleger, 2013). Therefore, there is some potential to apply comments from the NPO servant leader clergy to their secular counterparts.

\subsection{Implications}

Theory. This section describes the implications of this study interpreted by the researcher. The greater meaning of the results of this study to the servant leadership theory was the introduction to the possibility that a servant leader may not always serve first. The new follower relationship in a specific type of organization where the new followers experience little to no screening opened a prospect of teaching before serving. The research was conducted through the overall application of two research questions related to the practices, interactions, and approaches of participants. This was in relation to how the theory applies to servant leaders in the NPO of churches who establish a bond with new followers as leaders and how fellowship was instituted when that same leader was a new follower (Zou et al., 2015). The procedures of the IPA study were used through 
the development of semi-structured questions with a double hermeneutic interpretation of participant meaning of experiences along with researcher's interpretation of participant expression of meaning (Cope, 2011).

Practice. Within this study of the discovery of servant leaders in NPOs when dealing with new followers, the leading application of the results of this research is in the conception that the primary adage of the servant leadership theory as stated by Greenleaf (1977) that a servant leader is a servant first (Greasley \& Bocârnea, 2014; Liden et al., 2008; van Dierendonck, 2011) may not apply to all management settings. The greater meaning of this study as related to practice was that a new follower might have to be taught and trained to the level where they can be served. The IPA study of servant leadership with new followers in the NPO of the church revealed that the first step for a servant leader with new followers was to teach the new follower the basics of the faith to get them to the point where they could be served. The new follower within a church was unique as compared to other organizations' new followers because there was no screening (Resane, 2014). Little to no screening was not exclusive to new followers in the church as voluntary service organizations and some businesses in a hiring need could provide little to no screening before incorporating new followers (Van Winkle et al., 2014; Zou et al., 2015). The focus of the study was on the church as a NPO and the pastor as a servant leader manager over that organization (Wollschleger, 2013).

There were illuminating statements from the founder of the Christian church, Jesus, investigated as a philosopher as opposed to a religious leader. Scholars highly regard the teachings of Jesus to his disciples as prime examples of servant leadership (Parris \& Peachey, 2013a). During a conversation between Jesus and his disciple, Peter, in the book of John, Jesus detailed three mandates to Peter which were for Peter to "feed my lambs, tend my sheep, and feed my sheep" (John 21: 15-17, New King James Version). Every participant in this study interpreted lambs as new followers. Additionally, each servant leader in this study interpreted the word "feed" as teach and the word "tend" as serve or take care of. In reference to this portion of the scripture, Resane (2014) added that the servant leader, in the example of the term lambs, should teach basic information of the faith first. Then, when the follower progresses in knowledge enough to become sheep or a follower capable of exhibiting a base knowledge, the servant leader should take care of the sheep before teaching or feeding the sheep (Resane, 2014). The application to these monumental statements was to determine to experience level of the follower.

\subsection{Future Research}

For future research of this subject, a longitudinal qualitative case study may prove to be a strong possibility as the researchers can follow new followers in the NPO of the church over the extended period of one year (Parris \& Peachey, 2013b) to understand their experiences as strengthened or not strengthened by servant leadership. In this study, the researchers can attempt to analyze the ex- 
periences of the new follower when they were new followers and the effects of how servant leadership was applied toward them.

The Servant Leader Survey (SLS) quantitative study (van Dierendonck \& Nuijten, 2011), which was developed based off of Liden's multidimensional measure of servant leadership (Liden et al., 2008), can be another productive survey or surveys to follow-up this research investigation. A series of particular servant leadership questions developed by van Dierendonck \& Nuijten (2011) could be applied to a large number of new followers who have very little to no pre-screening across NPOs like the church and some voluntary service organizations. Likewise, some new followers in for-profit businesses in specific large hiring situations for certain jobs where job screening was minimal can be questioned.

\subsection{Conclusion}

The results and recommendations of this research study were presented as a significant yet possible minor change to servant leadership interactions when covering relations with new followers. Based preliminarily on this research study it could possibly be stated that a servant may teach first, instead of serve first, with new followers in specific situations. While this study focused on new followers in the church, it is conceivable that any NPO or for-profit organization where little to no screening occurs for the followers may be affected by the results of this research as related to the implementation of servant leadership. The suggestion of a small modification to servant leadership with new followers to teach first then serve, as potentially demonstrated from this research, may have provided a conceivable opening to clarify the servant leadership theory further in different and unique settings.

\section{References}

Adams, J. S. (1963). Towards an Understanding of Inequity. Journal of Abnormal \& Social Psychology, 67, 422-436. https://doi.org/10.1037/h0040968

Alvesson, M., \& Blom, M. (2015). Less Followership, Less Leadership? An Inquiry into the Basic but Seemingly Forgotten Downsides of Leadership. M@N@Gement, 8, 266282.

Arogundade, O. T., \& Arogundade, A. B. (2015). Psychological Empowerment in the Workplace: Implications for Employees' Career Satisfaction. North American Journal of Psychology, 17, 27-36.

Avis, P. (2016). Polity and Polemics: The Function of Ecclesiastical Polity in Theology and Practice. Ecclesiastical Law Journal, 18, 2-13. https://doi.org/10.1017/S0956618X15000800

Boggs, W. B., \& Fields, D. L. (2010). Exploring Organizational Culture and Performance of Christian Churches. International Journal of Organization Theory \& Behavior (Pracademics Press), 13, 305-334.

Boone, L. W., \& Makhani, S. (2012). Five Necessary Attitudes of a Servant Leader. Review of Business, 33, 83-96.

Burch, M. J., Swails, P., \& Mills, R. (2015). Perceptions of Administrators' Servant Lea- 
dership Qualities at a Christian University: A Descriptive Study. Education, 135, 399-404.

Burrai, E., Font, X., \& Cochrane, J. (2015). Destination Stakeholders' Perceptions of Volunteer Tourism: An Equity Theory Approach. International Journal of Tourism Research, 17, 451-459. https://doi.org/10.1002/jtr.2012

Carter, D., \& Baghurst, T. (2014). The Influence of Servant Leadership on Restaurant Employee Engagement. Journal of Business Ethics, 124, 453-464. https://doi.org/10.1007/s10551-013-1882-0

Choudhary, A., Akhtar, S., \& Zaheer, A. (2013). Impact of Transformational and Servant Leadership on Organizational Performance: A Comparative Analysis. Journal of Business Ethics, 116, 433-440. https://doi.org/10.1007/s10551-012-1470-8

Convery, I., Soane, I., Dutson, T., \& Shaw, H. (2010). Mainstreaming LEADER Delivery of the RDR in Cumbria: An Interpretative Phenomenological Analysis. Sociologia Ruralis, 50, 370-391. https://doi.org/10.1111/j.1467-9523.2010.00519.x

Cope, J. (2011). Entrepreneurial Learning from Failure: An Interpretative Phenomenological Analysis. Journal of Business Venturing, 26, 604-623. https://doi.org/10.1016/j.jbusvent.2010.06.002

Crippen, C. (2012). Enhancing Authentic Leadership-Followership: Strengthening School Relationships. Management in Education, 26, 192-198. https://doi.org/10.1177/0892020612439084

de Sousa, M. C., \& van Dierendonck, D. (2014). Servant Leadership and Engagement in a Merge Process under High Uncertainty. Journal of Organizational Change Management, 27, 877-899. https://doi.org/10.1108/JOCM-07-2013-0133

Deichmann, D., \& Stam, D. (2015). Leveraging Transformational and Transactional Leadership to Cultivate the Generation of Organization-Focused Ideas. The Leadership Quarterly, 26, 204-219. https://doi.org/10.1016/j.leaqua.2014.10.004

Epitropaki, O., \& Martin, R. (2013). Transformational-Transactional Leadership and Upward Influence: The Role of Relative Leader-Member Exchanges (RLMX) and Perceived Organizational Support (POS). The Leadership Quarterly, 24, 299-315. https://doi.org/10.1016/j.leaqua.2012.11.007

Ghasabeh, M. S., Reaiche, C., \& Soosay, C. (2015). The Emerging Role of Transformational Leadership. The Journal of Developing Areas, 49, 459-467. https://doi.org/10.1353/jda.2015.0090

Grandy, G. (2013). An Exploratory Study of Strategic Leadership in Churches. Leadership \& Organization Development Journal, 34, 616-638. https://doi.org/10.1108/lodj-08-2011-0081

Greasley, P. E., \& Bocârnea, M. C. (2014). The Relationship between Personality Type and the Servant Leadership Characteristic of Empowerment. Procedia-Social and Behavioral Sciences, 124, 11-19. https://doi.org/10.1016/j.sbspro.2014.02.454

Greenleaf, R.K. (1977). Servant Leadership: A Journey into the Nature of Legitimate Power and Greatness. New York: Paulist Press.

Hamstra, M., Van Yperen, N., Wisse, B., \& Sassenberg, K. (2014). Transformational and Transactional Leadership and Followers' Achievement Goals. Journal of Business \& Psychology, 29, 413-425. https://doi.org/10.1007/s10869-013-9322-9

Hoption, C. (2014). Learning and Developing Followership. Journal of Leadership Education, $13,129-137$.

Hunter, E. M., Neubert, M. J., Perry, S. J., Witt, L., Penney, L. M., \& Weinberger, E. (2013). Servant Leaders Inspire Servant Followers: Antecedents and Outcomes for Employees and the Organization. The Leadership Quarterly, 24, 316-331. 
https://doi.org/10.1016/j.leaqua.2012.12.001

Jacob, S. A., \& Furgerson, S. P. (2012). Writing Interview Protocols and Conducting Interviews: Tips for Students New to the Field of Qualitative Research. Qualitative Report, 17, 1-10.

Kessler, V., \& Kretzschmar, L. (2015). Christian Leadership as a Trans-Disciplinary Field of Study. Verbum et Ecclesia, 36, 1-8. https://doi.org/10.4102/ve.v36i1.1334

Leroy, H., Anseel, F., Gardner, W. L., \& Sels, L. (2015). Authentic Leadership, Authentic Followership, Basic Need Satisfaction, and Work Role Performance. Journal of Management, 41, 1677-1697. https://doi.org/10.1177/0149206312457822

Liden, R. C., Wayne, S. J., Zhao, H., \& Henderson, D. (2008). Servant Leadership: Development of a Multidimensional Measure and Multi-Level Assessment. The Leadership Quarterly, 19, 161-177. https://doi.org/10.1016/j.leaqua.2008.01.006

McGregor, D. (1960). The Human Side of Enterprise. New York: McGraw-Hill.

Moustakas, C. E. (1994). Phenomenological Research Methods. Thousand Oaks, CA: Sage Publications. https://doi.org/10.4135/9781412995658

Mullaney, E. (2014). Generational Preferences Create Challenges for Modern Mobility Strategies. Benefits Quarterly, 30, 38-40.

Mutch, A. (2012). Theology, Accountability and Management: Exploring the Contributions of Scottish Presbyterianism. Organization, 19, 363-379.

https://doi.org/10.1177/1350508412437071

Noland, A., \& Richards, K. (2015). Servant Teaching: An Exploration of Teaching Servant Leadership on Student Outcomes. Journal of the Scholarship of Teaching \& Learning, 15, 16-38. https://doi.org/10.14434/josotl.v15i6.13928

Parris, D. L., \& Peachey, J. W. (2013a). A Systematic Literature Review of Servant Leadership Theory in Organizational Contexts. Journal of Business Ethics, 113, 377-393. https://doi.org/10.1007/s10551-012-1322-6

Parris, D. L., \& Peachey, J. W. (2013b). Encouraging Servant Leadership: A Qualitative Study of How a Cause-Related Sporting Event Inspires Participants to Serve. Leadership, 9, 486-512. https://doi.org/10.1177/1742715012470675

Pfang, R. (2015). Management in the Catholic Church: Corporate Governance. Journal of Management, Spirituality \& Religion, 12, 38-58. https://doi.org/10.1080/14766086.2014.933708

Rahn, D. L., Jawahar, J., Scrimpshire, A. J., \& Stone, T. (2016). Are Leaders Defined by Followers? Role of Follower's ILT and the Mediating Influence of LMX on Follower Outcomes. Journal of Organizational Effectiveness: People and Performance, 3, 43-69.

Read III, J. B. (2014). Followership at the FDIC: A Case Study. Journal of Leadership Education, 13, 136-145.

Renko, M., Kroeck, K., \& Bullough, A. (2012). Expectancy Theory and Nascent Entrepreneurship. Small Business Economics, 39, 667-684. https://doi.org/10.1007/s11187-011-9354-3

Resane, K. T. (2014). Leadership for the Church: The Shepherd Model. HTS Teologiese Studies/ Theological Studies, 70, 1-6. https://doi.org/10.4102/hts.v70i1.2045

Schneider, S., \& George, W. (2011). Servant Leadership versus Transformational Leadership in Voluntary Service Organizations. Leadership \& Organization Development Journal, 32, 60-77. https://doi.org/10.1108/01437731111099283

Schwepker, C. H., \& Schultz, R. J. (2015). Influence of the Ethical Servant Leader and Ethical Climate on Customer Value Enhancing Sales Performance. Journal of Personal Selling \& Sales Management, 35, 93-107.

https://doi.org/10.1080/08853134.2015.1010537 
Sendjaya, S. (2015). Servant Leadership Research. In Sendjaya, S., Personal and Organizational Excellence through Servant Leadership (pp. 15-38). Switzerland: Springer International Publishing. https://doi.org/10.1007/978-3-319-16196-9_2

Sendjaya, S., \& Sarros, J.C. (2002). Servant Leadership: Its Origin, Development, and Application in Organizations. Journal of Leadership and Organization Studies, 9, 57-64. https://doi.org/10.1177/107179190200900205

Smith, J. A., Flowers, P., \& Larkin, M. (2009). Interpretative Phenomenological Analysis: Theory, Method and Research. Thousand Oaks, CA: Sage Publications.

Spears, L. C. (2010). Character and Servant Leadership: Ten Characteristics of Effective, Caring Leaders. The Journal of Virtues \& Leadership, 1, 25-30.

Sun, P. Y. (2013). The Servant Identity: Influences on the Cognition and Behavior of Servant Leaders. The Leadership Quarterly, 24, 544-557. https://doi.org/10.1016/j.leaqua.2013.03.008

Țebeian, A. E. (2012). The Impact of Motivation through Leadership on Group Performance. Review of International Comparative Management/Revista De Management Comparat International, 13, 313-324.

Tseng, L., \& Kuo, C. (2014). Customers' Attitudes toward Insurance Frauds: An Application of Adams' Equity Theory. International Journal of Social Economics, 41, 10381054. https://doi.org/10.1108/IJSE-08-2012-0142

van Dierendonck, D. (2011). Servant Leadership: A Review and Synthesis. Journal of Management, 37, 1228-1261. https://doi.org/10.1177/0149206310380462

van Dierendonck, D., \& Nuijten, I. (2011). The Servant Leadership Survey: Development and Validation of a Multidimensional Measure. Journal of Business \& Psychology, 26, 249-267. https://doi.org/10.1007/s10869-010-9194-1

van Dierendonck, D., \& Patterson, K. (2015). Compassionate Love as a Cornerstone of Servant Leadership: An Integration of Previous Theorizing and Research. Journal of Business Ethics, 128, 119-131. https://doi.org/10.1007/s10551-014-2085-Z

van Dierendonck, D., Stam, D., Boersma, P., de Windt, N., \& Alkema, J. (2014). Same Difference? Exploring the Differential Mechanisms Linking Servant Leadership and Transformational Leadership to Follower Outcomes. The Leadership Quarterly, 25, 544-562. https://doi.org/10.1016/j.leaqua.2013.11.014

Van Winkle, B., Allen, S., De Vore, D., \& Winston, B. (2014). The Relationship between the Servant Leadership Behaviors of Immediate Supervisors and Followers' Perceptions of Being Empowered in the Context of Small Business. Journal of Leadership Education, 13, 70-82.

Vroom, V.H. (1964). Work and Motivation. New York: Wiley.

Wagstaff, C., \& Williams, B. (2014). Specific Design Features of an Interpretative Phenomenological Analysis Study. Nurse Researcher, 21, 8-12. https://doi.org/10.7748/nr2014.01.21.3.8.e1226

Washington, R. R., Sutton, C. D., \& Sauser, J. I. (2014). How Distinct Is Servant Leadership Theory? Empirical Comparisons with Competing Theories. Journal of Leadership, Accountability \& Ethics, 11, 11-25.

Watt, W. M. (2014). Relational Principles for Effective Church Leadership. Journal of Leadership Education, 13, 125-139.

Wollschleger, J. (2013). Church Government and Religious Participation. Rationality \& Society, 25, 470-488. https://doi.org/10.1177/1043463113504449

Wong, P.T.P., \& Davey, D. (2007). Best Practices in Servant Leadership. Paper presented at the Servant Leadership Roundtable at Regent University, Virginia Beach, VA, July 2007. 
Zhong, J., Lam, W., \& Chen, Z. (2011). Relationship between Leader-Member Exchange and Organizational Citizenship Behaviors: Examining the Moderating Role of Empowerment. Asia Pacific Journal of Management, 28, 609-626.

https://doi.org/10.1007/s10490-009-9163-2

Zou, W., Tian, Q., \& Liu, J. (2015). Servant Leadership, Social Exchange Relationships, and Follower's Helping Behavior: Positive Reciprocity Belief Matters. International Journal of Hospitality Management, 51, 147-156.

https://doi.org/10.1016/j.ijhm.2015.08.012

Scientific Research Publishing

Submit or recommend next manuscript to SCIRP and we will provide best service for you:

Accepting pre-submission inquiries through Email, Facebook, LinkedIn, Twitter, etc. A wide selection of journals (inclusive of 9 subjects, more than 200 journals)

Providing 24-hour high-quality service

User-friendly online submission system

Fair and swift peer-review system

Efficient typesetting and proofreading procedure

Display of the result of downloads and visits, as well as the number of cited articles Maximum dissemination of your research work

Submit your manuscript at: http://papersubmission.scirp.org/

Or contact ojl@scirp.org 